\title{
Homeobox Protein CDX-2
}

National Cancer Institute

\section{Source}

National Cancer Institute. Homeobox Protein CDX-2. NCI Thesaurus. Code C25899.

Homeobox protein CDX-2 (313 aa, $\sim 34 \mathrm{kDa}$ ) is encoded by the human CDX2 gene. This protein is involved in transcription and intestinal morphogenesis. 